\title{
Otolith shape as a tool for representing different growth in young and adult yellowfin tuna (Thunnus albacares, Bonnaterre, 1788)
}

\author{
Ririk Kartika Sulistyaningsih ${ }^{1, *}$, Bram Setyadji ${ }^{1}$, Hety Hartaty ${ }^{1}$, and Arief Wujdi ${ }^{1}$ \\ ${ }^{1}$ Research Intitute for Tuna Fisheries, Denpasar, Bali, 80233, Indonesia
}

\begin{abstract}
The stock status of yellowfin tuna (Thunnus albacares) (YFT) in the Indian Ocean is currently concluded overfished and is subject to overfishing. The information about the YFT population structure is fundamental for effective fisheries management and conservation. The otolith shape as a tool for estimating population structure is the cheapest technique compared to other methods, such as genetic, parasite, and otolith chemistry, especially for analyzing the large samples. This study investigates the use of otolith shapes to determine the yellowfin stock from two different locations. Data collection was carried out at two locations, namely Kedonganan and Benoa, throughout 2018. Total samples collected from the two study sites were 314 otoliths, but only 147 whole otoliths could be analyzed. Image analysis was performed using ANOVA-like permutation $(n=1000$ to determine whether the individual can be reclassified to their sample origin. The subsequent analysis is the variations in the shape of the otolith with multivariate statistical methods using cluster analysis with Canonical Analysis of Principal Coordinates. The result shows that the YFT otolith Benoa is significantly different from the YFT otolith Kedonganan with the P-value $=0.0015$.
\end{abstract}

\section{Introduction}

Yellowfin tuna (Thunnus albacares) (YFT) is a cosmopolitan species distributed in both tropical and sub-tropical water [1], which were also the main targeted fish in the Indian Ocean fisheries [2]. YFT is an export commodity category with high value in Indonesia, but the population decreases [3]. YFT stock status in the Indian Ocean based on IOTC analysis in 2018 reported overfished and is subject to overfishing [4].

Numerous studies to discriminate stock structure have been conducted using various methods. Genetic techniques have been commonplace for at least 25 years [5]. Parasite studies have the potential to reveal migration patterns, habitat, and nursery information and find out the history of direct and indirect infections [5]. Direct parasitic infection occurs when the parasite is directly attached to or into the fish, whereas indirect disease originates from prey consuming infected fish [5]. Otolith chemistry has also proven to be a valuable tool in inferring population structure and ontogenic migration. For example, in 2016 found that 180

\footnotetext{
* Corresponding author: rk.sulistyaningsih11@gmail.com
} 
and 13C levels in the otoliths of BET and YFT juveniles (age 1 and 2+) were influenced by fish movement and local production from the environment experienced by fish [6].

Otoliths are a pair of crystals or calcium carbonate concretions located in all Teleostei's inner ear, containing $\mathrm{Li}, \mathrm{Mg}, \mathrm{Ca}, \mathrm{Mn}, \mathrm{Sr}$, and $\mathrm{Ba}$ [7, 8]. Variability between species causes their specific characteristics of the sagittal otoliths [8]. The otoliths on fish are used for the hearing and balancing system [8]. Furthermore, otolith can be used as a tool for stock structure discrimination and population connectivity [8]. In general, understanding the stock structure will be possible to prevent overfishing [5]. Otolith shape analysis has been proved to be an accurate method for identifying stock structure on some species, including striped trumpeter, European sardine, herring, and cod [9-13].

In addition to genetic, otolith chemistry, and parasitic techniques, otolith shape analysis has proven to be a cost and time-efficient technique, for dealing with the population structure of several fish species, with the ability to examine large samples quickly and accurately [9, $14,15]$. Fish diets, feeding areas, growth patterns of individuals, cohorts, and populations have been interpreted through otolith shape, and the results have been shown to be highly specific $[16,17]$. Identifying different fish stocks using multivariate analysis of otolith shape data has also been proven [18, 19] and detecting diverse stock situations [20]. Previous studies in which otolith shape analysis proved useful for population structure identification include those in European sardines, herring, striped trumpeter, cod, and especially for juvenile stages of these species [9-13].

YFT is still assumed to be a single stock unit [1], so biological evidence is needed to estimate the YFT population structure. This research aims to analyze the shape of the YFT otolith from 2 different locations using shapeR. The

\section{Materials and methods}

\subsection{Sample collection}

The fish identification process was based on Itano's handbook [21], which explained the difference between YFT and BET through their livers. YFT livers have the right lobes longer than the left one, where BET has the equal shape of their three lobes. The otolith samples were collected from 2 fishing ports, Benoa and Kedonganan (Fig. 1), in 2018. A total of 78 YFT were obtained with a fork length range of 85-164 cm and Kedonganan a total of 69 YFT measurings 24-94 cm. These two fishing ports have their characteristics; Benoa is an industrial fishing port where the big YFT size landed, whereas Kedonganan is a small-scale fishery for collecting the small size of YFT. The fishing gears used in both fisheries are also different. Benoa operated a tuna longline while Kedonganan fished using a handline. The parameters were recorded, including fish length (to nearest $0.5 \mathrm{~cm} \mathrm{FL}$.), fish weight $(\mathrm{kg})$, sampling date, and fishing ground (as best known). 


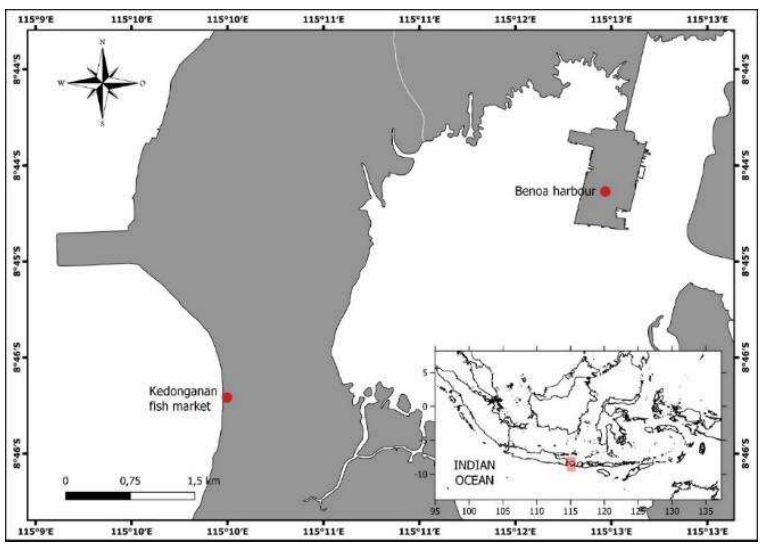

Fig. 1. Sampling locations (Benoa and Kedonganan).

A total of 314 otoliths were collected from those two sampling locations. Only the unbroken otoliths were used in this research, while the broken ones were excluded from the sampling collection to keep the integrity of the otolith shapes for analysis. A pair of otoliths (left and right) was extracted from the fish head with two different methods (Fig. 2). A drilling process (up through the gill) is needed to get the otolith from the big fish. Meanwhile, the opening the head method was used for otolith extraction of the smaller fish.

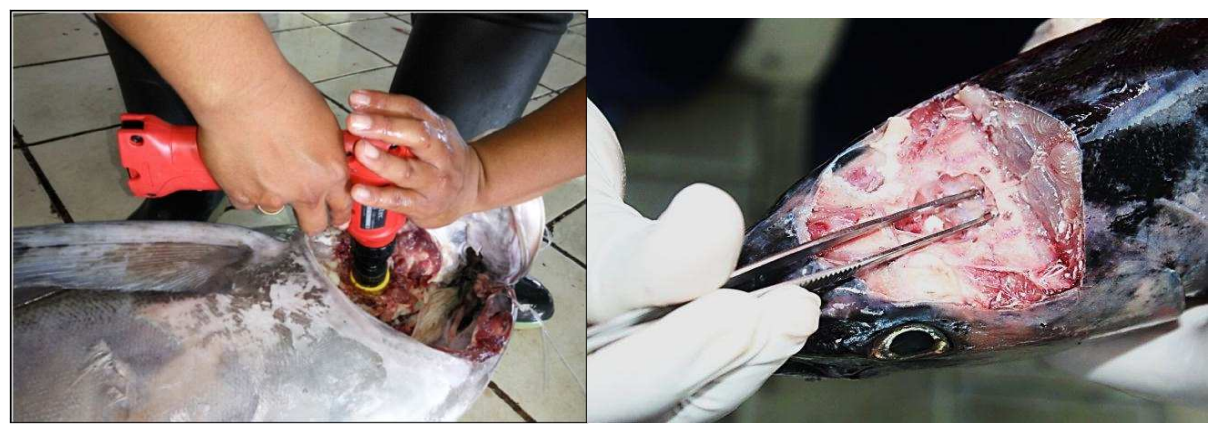

Fig. 2. Otolith extraction for big (left) and small fish (right).

\subsection{Otolith picture format}

Otolith images are taken under a stereo microscope connected to a camera and monitor screen. A black background is used to get the highest quality image because poor image quality will be rejected by shapeR. The otolith image format is JPEG so that it can be analyzed using shapeR. Only one is randomly selected for analysis if there is a pair of right and left otolith images in one fish. The position of the image is that the otolith rostrum should face the same direction (left/right). The XnConvert program was used in this study to enhance image contrast and reverse the position of the otolith image, for example, flipping a right otolith whose rostrum is facing right to facing left. 


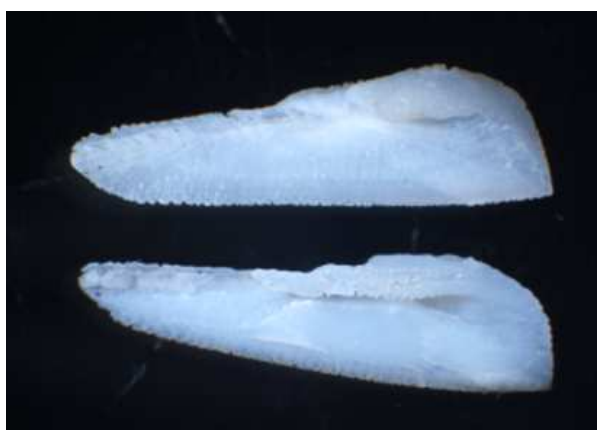

Fig. 3. YFT otolith picture processing.

\subsection{Data set}

The data set needed in this study consisted of 1 original otolith image folder, one otolith image folder clarified in contrast, and 1 excel file in * csv format. Of the total 314 YFT otolith samples, only 147 unbroken otoliths could be analyzed (Table 1). The range of YFT fork lengths of the 147 otoliths is presented in Fig. 4. Broken otoliths (part or all of the rostrum) were excluded from the analysis to maintain the integrity of the analyzed otolith shape. The results of measuring the fork length of 147 YFTs at the two research sites are presented in Fig. 4. A total of 78 YFT were obtained with a fork length range of $85-164 \mathrm{~cm}$ and Kedonganan a total of 69 YFT measurings $24-94 \mathrm{~cm}$.

Table 1. The otolith number from both sampling location and the fish length

\begin{tabular}{lll}
\hline Location & Otolith samples (n) & Fork length (cm) \\
\hline Benoa & 78 & $85-164$ \\
Kedonganan & 69 & $24-94$ \\
\hline
\end{tabular}

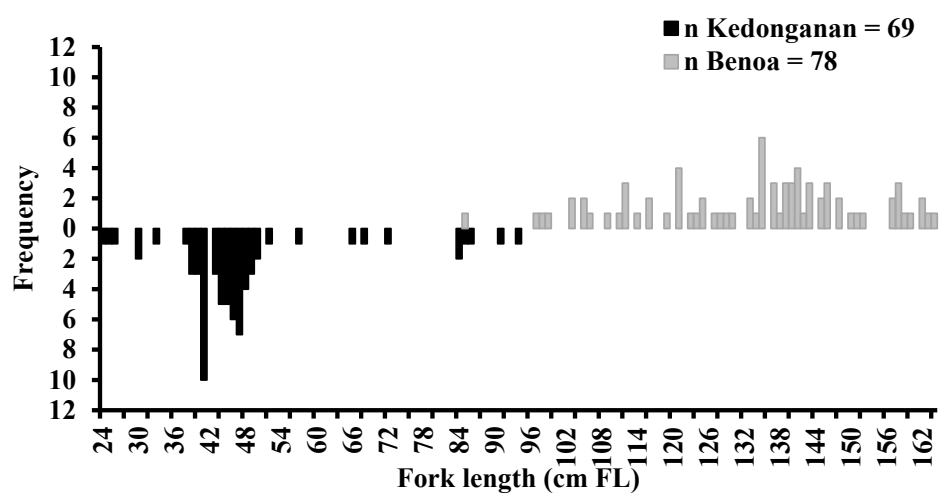

Fig. 4. YFT length frequency $(\mathrm{cm})$ from Benoa dan Kedonganan.

\subsection{Otolith shape analysis}

The otolith shape analysis method includes ellipticity, rectangularity, roundness, perimeter length, circularity, form-factor, and aspect ratio $[11,13]$. The working principle of ShapeR is to visualize the otolith image by obtaining the outline of the otolith framework (Fig. 5) and smoothing the lines to produce two otolith shape coefficients, Wavelet and Fourier [22]. 
These coefficients were then analyzed using other R software packages, namely: i) gplot to test the variation of the two coefficients; ii) vegans to analyze the variation in otolith shape between groups using ANOVA-like permutation $(n=1000)$; iii) ipred and lda to determine whether the individual can be reclassified to their sample origin. The following analysis is the analysis of variations in the shape of the otolith with multivariate statistical methods using cluster analysis with Canonical Analysis of Principal Coordinates [23]. The analysis chosen in this study is in the form of an outline analysis approach so that the results obtained can describe the outer boundaries of the otolith quantitatively, which allows the evaluation process of the pattern of variations in the shape of the otolith between different fish populations and within the same population $[24,25]$.

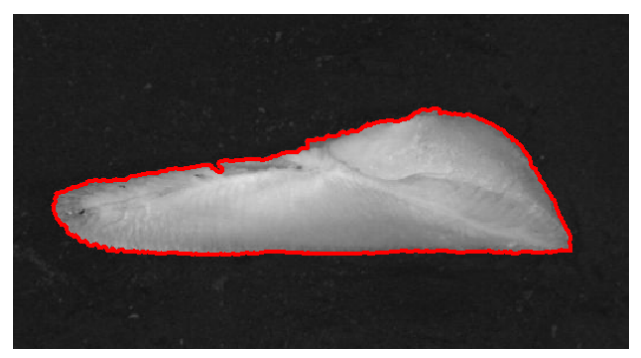

Fig. 5. The otolith image example with the red outline extracted by shapeR.

\section{Results and discussion}

\subsection{Results}

The results of shapeR show that the average size of the YFT otolith landed in Benoa is larger than that of Kedonganan (Table 2). This result is presumably due to the uneven distribution of the length of the fish sampled. The YFT sampled in Benoa was bigger than the Kedonganan YFT, so the otolith shape of the adult fish was different from that of the young fish.

Table 2. YFT otolith means from both locations Benoa and Kedonganan from shapeR analysis.

\begin{tabular}{lrr}
\hline \multirow{2}{*}{ Variables } & Mean size & Kedonganan \\
\cline { 2 - 3 } & Benoa & 0,73 \\
Otolith area $\left(\mathrm{mm}^{2}\right)$ & 1,79 & 1,71 \\
Otolith length $(\mathrm{mm})$ & 3,02 & 0,58 \\
Otolith width $(\mathrm{mm})$ & 0,85 & 4,03 \\
Otolith perimeter $(\mathrm{mm})$ & 6,72 & \\
\hline
\end{tabular}

The analysis of variance (ANOVA) showed that the YFT otolith shape landed in Benoa was significantly different from that landed in Kedonganan $\left(\mathrm{P}=0.015^{*}\right)$. The result is indicated by a significant difference in the shape of the otolith in the four quadrants of the mean value based on the reconstruction of the Wavelet coefficient combined with angles, especially at $90-180$ degrees and $0-270$ degrees (Fig. 6). 
Table 3. YFT otolith shape comparison from Benoa and Kedonganan using ANOVA- like permutation $(\mathrm{n}=1.000)$

\begin{tabular}{lrrrr}
\hline \multirow{2}{*}{ Method } & \multicolumn{4}{c}{ ANOVA-like permutation (n=1.000) } \\
\cline { 2 - 5 } & df & SS & F & P \\
\hline Benoa vs Kedonganan & 1 & 0,1562 & 5,5219 & $0,015^{*}$ \\
Residual & 141 & 4,1943 & & \\
\hline
\end{tabular}

* $\mathrm{P} \leq 0.05$

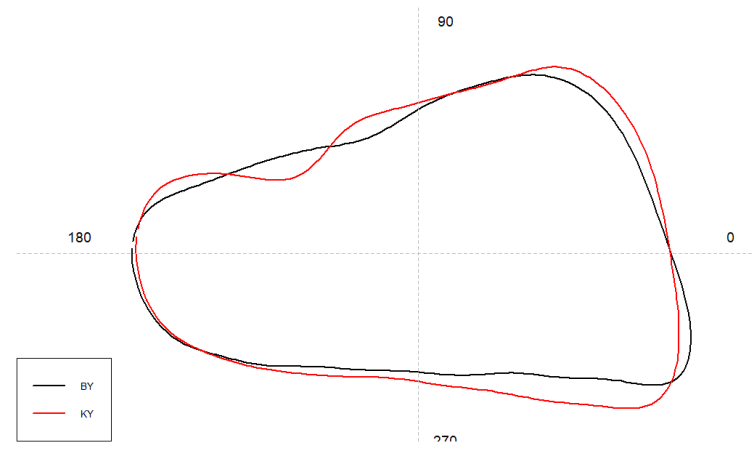

Fig. 6. The average of YFT otolith shape from both locations Benoa and Kedonganan based on Wavelet coefficient with degree unit $\left(^{\circ}\right)$.

Canonical Analysis of Principal Coordinates provides more accurate analysis results if there is a similarity between the number of variables and the measured parameters [26]. The CAP cluster analysis results explained a $100 \%$ difference in otolith shape between the two YFT populations indicated by the first axis (CAP1) (Fig. 7). The resulting canonical score indicates that YFT Benoa and YFT Kedonganan come from different populations.

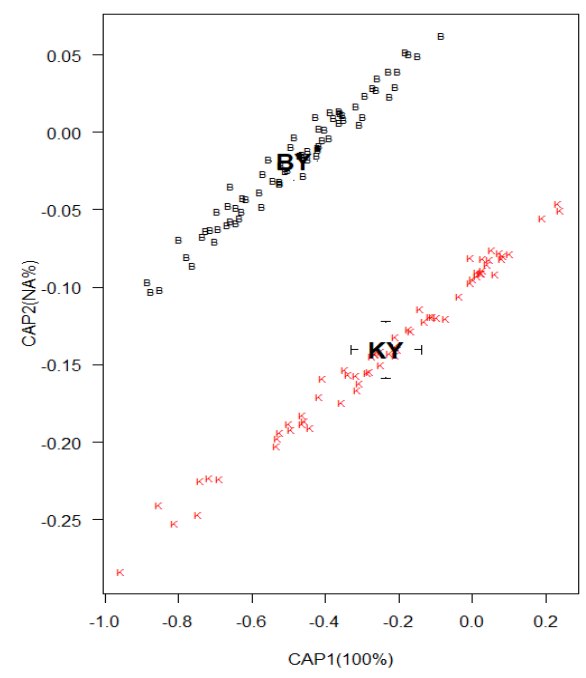

Fig. 7. Canonical score from Wavelet discriminant coefficient one dan two for each YFT population (BY=Benoa YFT; KY=Kedonganan YFT). 


\subsection{Discussions}

This study was conducted in the two different fisheries types, industrial (Benoa) and small scale (Kedonganan), to test the function of otolith shape as a tool for representing different growth in young and adult YFT. Although the distance between those two landing sites is only about $6 \mathrm{~km}$, the types of fishing gear used and the fishing grounds are very different. The fishing area for tuna longline vessels based in Benoa Harbor is at coordinates $00^{\circ} 37^{\prime}$ $33^{\circ} 54^{\prime}$ South and $078^{\circ} 51^{\prime}-133^{\circ} 40^{\prime}$ East [27]. In contrast, the fishing ground for hand-line fishers based at the Kedonganan Fish Landing covers the fish aggregating devices area of south Bali to Lombok or at a position $114^{0}-116^{0}$ East and $10^{\circ}-12^{0}$ South [28].

YFT landed in Benoa and was assumed as adult fish, where the young YFT landed in Kedonganan. The growth phase between young and adult fish is also different, where young fish have a slower growth phase when compared to adult fish, especially in YFT [29], thus affecting variations in the shape of the otolith.

Otolith size analysis, which includes area, length, width, and circumference, is a straightforward method and is recommended to differentiate fish population structure [30]. Factors of food availability, genetics, protein deposits, and the growth phase of young fish into adults influence variations in the shape and otoliths' growth [15, 31, 32]. Variations in the otolith shape can be influenced by environmental factors, such as salinity and temperature, which will affect the growth phase (young/adult) of the fish [16,33].

Other methods of stock discrimination of YFT using genetic in three different locations in Indonesia waters concluded a single stock [34]. This study is in line with the parasite findings in the Eastern Indian Ocean FMA 572 and 573, which showed a minimum movement of young YFT [35]. Further study on YFT otolith shape is highly recommended to obtain more robust stock separation results.

\section{Conclusion and recommendation}

Of the total 314 YFT otolith samples collected, only 46.82\% (147 otoliths) were unbroken and could be analyzed for shape to obtain information about the YFT population structure from the two different locations. The shape analysis of the otoliths shows that the mature YFT otolith that landed in the Benoa harbor is significantly different from that of the young YFT otolith from Kedonganan. That result illustrates that YFT Benoa comes from a different population from YFT Kedonganan. The results of this analysis can be used as recommendations for sustainable management of YFT commodities, especially in the Indian Ocean, Fisheries Management Area 572.

\section{Acknowledgements}

This research was funded by the Research Institute for Tuna Fisheries year 2018 in the study entitled Research structure, stock parameters, and estimation production of tuna, skipjack, and neritic tuna in the Indian Ocean. The authors would like to thank the researchers, enumerators, supervisors, and laboratory analysts of the RITF who were preparing this paper.

\section{References}

1. R. Shuford, et al., Sci. Pap. ICCAT. 60, 1 (2007)

2. B. Stéquert, J. Panfili, J. Dean, Oceanogr. Lit. Rev. 12, 43 (1996)

3. J.H. Hutapea, et al., J. RisAkuakultur 12, 1 (2017) 
4. IOTC, Report of the 20th session of the IOTC working party on tropical tunas (IOTC, Seychelles, 2018)

5. R.E. Baldwin, M.A. Banks, K.C. Jacobson, Rev. Fish Bio. Fish. 22, 1 (2012)

6. J.R. Rooker, et al., Fish. Oceanogr. 25, 3 (2016)

7. R.R. Mendoza, Ribar. Croat. J. Fish. 64, 3 (2006)

8. C. Platt, A.N. Popper, Proceedings in Life Sciences, 88 (1981)

9. J.L. Bird, D.T. Eppler, D.M. Checkley Jr, Can. J. Fish. Aquat. 43, 6 (1986)

10. K. Hüssy, J. Exp. Mar. Biol. Ecol. 364, 1(2008)

11. S. Jemaa, et al., J. Sea Res. 96, 11-17 (2015)

12. S.R. Tracey, J.M. Lyle, G. Duhamel, Fish. Res. 77, 2 (2006)

13. J. Mapp, et al., Fish. Res. 190, 43-52 (2017)

14. D. Brophy, et al., Mar. Freshwater Res. 67, 7 (2016)

15. M. Vignon, F. Morat, Mar. Ecol. Prog. Ser. 411, 231-241 (2010)

16. S.E. Campana, J.M. Casselman, Can. J. Fish. Aquat. 50, 5 (1993)

17. A. Benzinou, et al., Fish. Res. 143, 153-160 (2013)

18. G.A. Begg, W.J. Overholtz, N.J. Munroe, Fish. Bull. 99, 1 (2001)

19. K. Paul, R. Oeberst, C. Hammer, J. Appl. Ichthyol. 29, 4 (2013).

20. J.P.Keating, et al., Fish. Res. 157, 1-6 (2014)

21. D. Itano, A handbook for the identification of Yellowfin and Bigeye Tunas in Fresh Condition (Pelagic Fisheries Research Program, Hawaii, 2005)

22. L.A. Libungan, S. Pálsson, PLoS ONE 10, 3 (2015)

23. M.J. Anderson, Canonical analysis of principal coordinates (University of Auckland, Auckland, 2004)

24. C. Stransky, et al., Fish. Res. 90, 1-3 (2008)

25. C. Stransky, et al., Fish. Res. 89, 2 (2008)

26. M.J. Anderson, T.J. Willis, Ecol. 84, 2 (2003)

27. I. Jatmiko, B. Nugraha, F. Satria, Mar. Fish.: J. of Marine Fisheries Technology and Management 6, 1 (2015)

28. R.K. Sulistyaningsih, A. Barata, K. Siregar, J. Penelitian Perikanan Indonesia 17, 3 (2017)

29. J.P. Eveson, et al., Fish. Res. 163, 58-68 (2015)

30. K.L. Bolles, G.A. Begg, Fish. Bull. 98, 3 (2000)

31. L.A. Libungan, et al., PloS One 10, 6 (2015)

32. B. Reichenbacher, G.R. Feulner, T. Schulz-Mirbach, J. Morphol. 270, 4 (2009)

33. Sadighzadeh, Z., et al., Fish. Res. 2014. 155 (2014)

34. I. Jatmiko, F. Rochman, M. Agustina, J. Penelitian Perikanan Indonesia (JKPI). 24, 3 (2018)

35. B.R. Moore, et al., ICES J. Mar. Sci. 76, 6 (2019) 